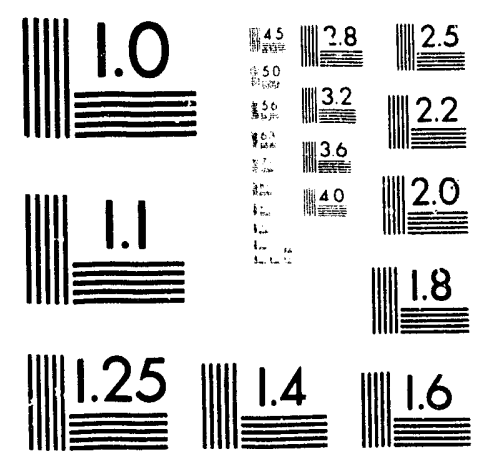



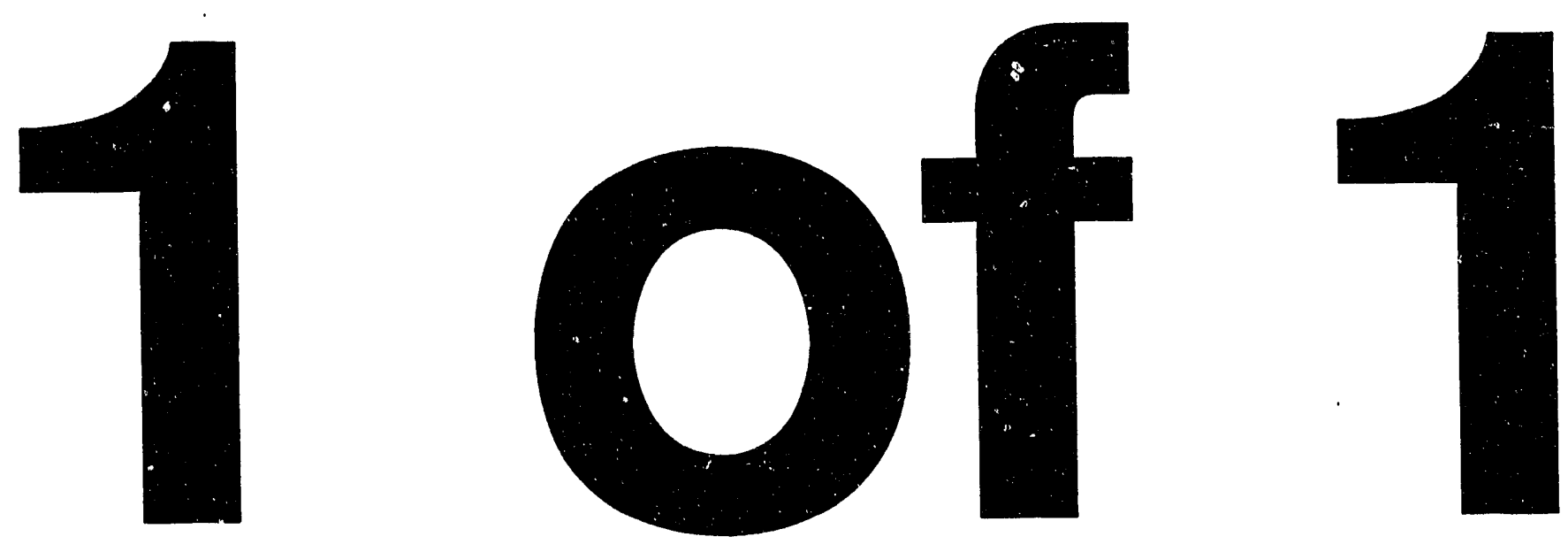
SSCL-Preprint-489

\title{
Cryogenic Systems for the SSC and the Status of Their Development*
}

\author{
W. Fietz, V. Ganni, S.Abramovich, and T. Niehaus \\ Superconducting Super Collider Laboratory ${ }^{\dagger}$ \\ 2550 Beckleymeade Ave. \\ Dallas, TX 75237
}

July 1993

"Presented at the International Cryogenics Engineering Conference, July 12-14, Albuquerque, N.M. ${ }^{+}$Operated by the Universities Research Association, Inc., for the U.S. Department of Energy under Contract No. DE-AC35-89ER40486. 


\title{
CRYOGENIC SYSTEMS FOR THE SSC AND THE STATUS OF THEIR DEVELOPMENT
}

\author{
W. A. Fietz, V. Ganni, S. Abramovich, and T. Niehaus \\ Cryogenics Department. Accelerator Systems Division \\ Superconducting Super Collider Laboratory* \\ 2550 Beckleymeade Avenue \\ Dallas, TX 752.37
}

\section{INTRODUCTION}

The Superconducting Super Collider (SSC) consists of two parallel magnet rings, each $87,120 \mathrm{~m}$ in circumference, constructed in a tunnel 25 to $74 \mathrm{~m}$ underground. Protons are injected into these ring from the high energy booster (HEB), which contains a separate magnet ring $10,800 \mathrm{~m}$ in circumference constructed in a tunnel $14 \mathrm{~m}$ above the collider tunnel. Figure 1 is a schematic of the collider and HEB rings. The magnets will be operated at a controlled low temperature in order to maintain the windings in the superconducting state. Therefore the magnet cryostat is designed with a high vacuum insulating chamber, multilayer insulation (MLI), and thermal shields at $84 \mathrm{~K}$ and $20 \mathrm{~K}$ nominal temperatures. The major portion of the heat load is from thermal radiation and conduction through the supports, and is intercepted and absorbed by the shields.

The cryogenic system for the machine is divided into sectors of nominally equal length: ten for the collider (including both upper and lower rings) and two for the HEB. Each sector has a dedicated cryogenic system (SCS) as well as some level of redundancy from the neighboring SCS. The helium refrigeration plants will be installed at the midpoint of each sector, as shown in Figures 1 and 2. Each cryogenic sector in the collider is divided into four strings, two upper and two lower, about $4000 \mathrm{~m}$ long. Each string is subdivided into sections of about $1080 \mathrm{~m}$, the smallest modules that can be isolated for maintenance, or for warmup arid cooldown. Each section is subdivided into cells and half cells. The half cell, containing six main magnets (five dipoles and one quadrupole) and a spool piece (a special box for cryogenics, vacuum, electrical, and beam physics measurements and controls), is $90 \mathrm{~m}$ long.

The SSC cryogenic system for each sector consists of a sector refrigerator surface system (SRS) and a sector refrigerator tunnel system (SRT). Proposals for the SRS systems ${ }^{1}$ are presently in review for vendor selection. In this paper the SRT subsystems requirements and their status will be reviewed.

\footnotetext{
*Operated by the Universities Research Association, Inc., for the U.S. Department of Energy under Contract No. DE-AC35-89ER40486.
} 


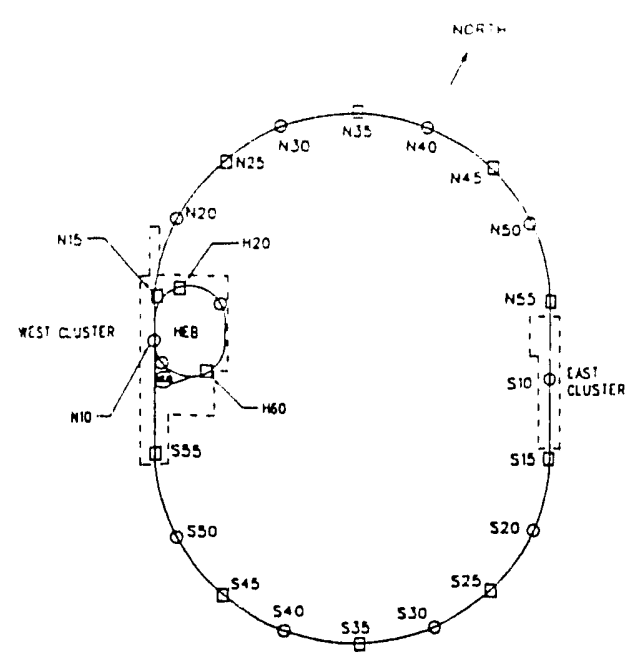

Figure 1. Helium refrigeration plants at the SSC, with location of cryogenic plants [U] and sector boundaries [0].

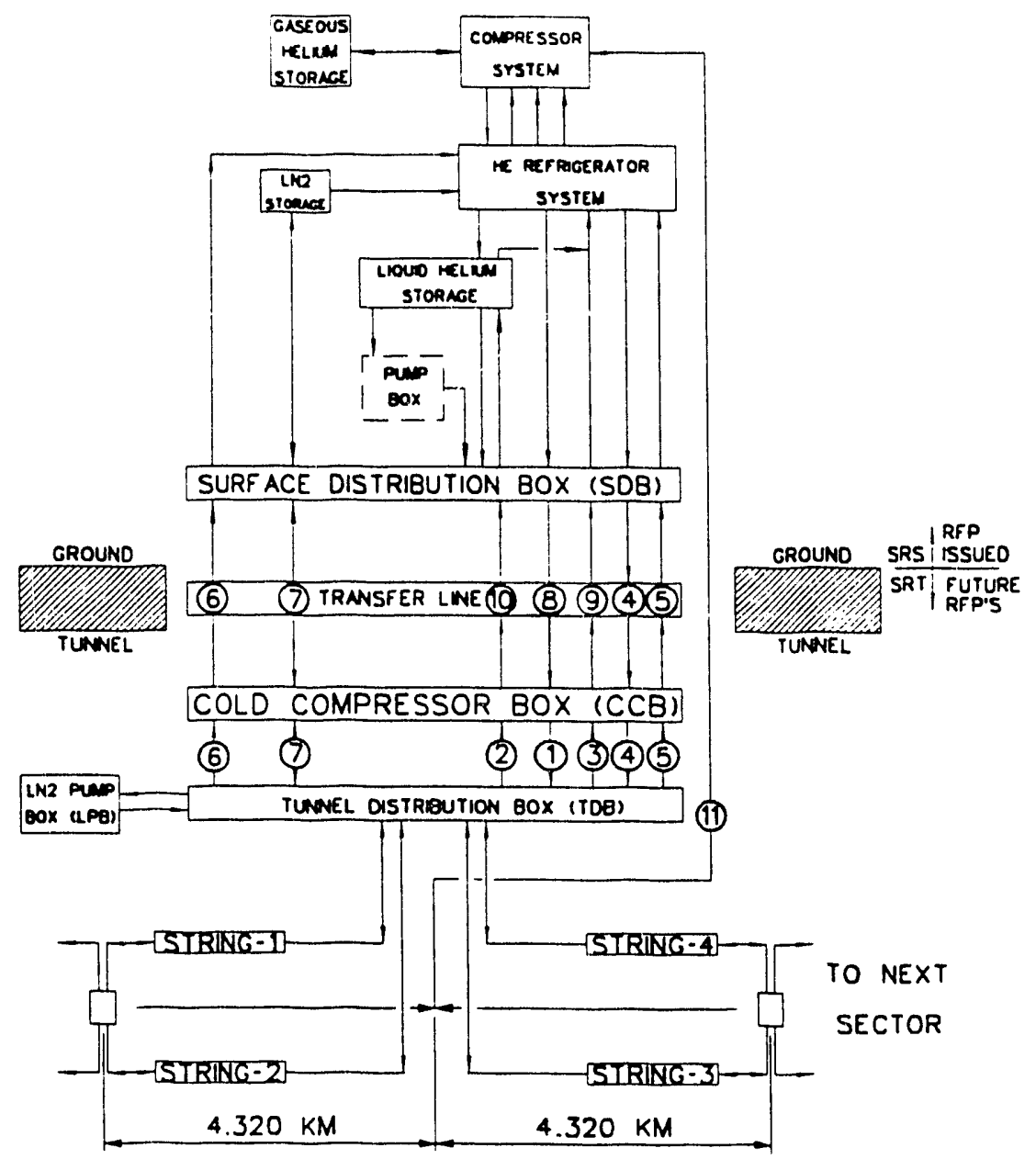

Figure 2. Sector cryogenic system (SCS). 


\section{CRYOGENIC TUNNEL SUBSYSTEM}

The helium refrigeration plants. $1,2,3$ which provide the $4-K$ and 2()$-K$ refrigeration and the lead cooling llow. will be installed above ground at the midpoint of each sector. Nitrogent dewars will also be provided at these sites. communicating with the magnet rings for 84-K shield cooling. The sector refrigerator surface systems (SRS), whose capacity requirements are shown in Table 1, are connected to the magnet rings through the sector refrigerator tunnel system (SRT) (Figure 2). The SCS operating conditions are given in Table 2.

The SRT consists of shatt transfer lines (STL), cold compressor box (CCB), tunnel distribution box (TDB), nitrogen pump box (NPB), and other tunnel equipment. For the SRT systems, process flow diagrams were developed for each subsystem to cover all the requirements. In addition, eertain mechanical conceptual designs were developed to define the space. interfaces, and installation requirements.

At the boundary between each two sectors an auxiliary valve box will control the flow of cryogens from one sector to the other and the return flows to the refrigerator. Nitrogen subcoolers will he installed and connected to isolation spools, which are at the end of each section (every $1080 \mathrm{~m}$ ). These subcoolers are heat exchangers that periodically recool the shield liquid nitrogen flow.

In several locations along the rings, warm equipment will be installed in series with the superconducting magnets. Cryogens will flow around these warm sections using cryogenic bypass transfer lines (CBTL). These transfer lines contain cryogenic pipes and cold superconducting buses that must be maintained at $4 \mathrm{~K}$. The connecting boxes to the cold magnets and the special boxes for recoolers, vacuum barriers. and cryogenics and vacuum instrumentation, together with the CBTL, are all part of the SRT.

Table 1. SCS capacity requirements.

\begin{tabular}{lcc}
\hline & Sector Heat Load & Plant Capacity \\
\hline 4-K Refrigeration & $5400 \mathrm{~W}$ & $6750 \mathrm{~W}$ \\
4-K Liquefaction & $36 \mathrm{~g} / \mathrm{s}$ & $45 \mathrm{~g} / \mathrm{s}$ \\
20)-K Refrigeration & $10,000 \mathrm{~W}$ & $15,000 \mathrm{~W}$ \\
\hline
\end{tabular}

Table 2. Sector cryogenic system (SCS) operating conditions.

\begin{tabular}{|c|c|c|c|c|c|c|c|}
\hline \multirow{2}{*}{$\begin{array}{l}\text { Fig. } 2 \\
\text { Ref. }\end{array}$} & \multirow[b]{2}{*}{ Cryogenic Circuits } & \multirow[t]{2}{*}{$\mathrm{T}(\mathrm{K})$} & \multicolumn{2}{|c|}{$\mathrm{P}$ (bar) } & \multicolumn{2}{|c|}{ Flow Rate $(\mathrm{g} / \mathrm{s})$} & \multirow{2}{*}{$\begin{array}{l}\text { Size } \\
(\mathrm{mm}) \\
\end{array}$} \\
\hline & & & Design & Nom. & Design & Nom. & \\
\hline 1 & $4 \mathrm{~K} \mathrm{He}$ supply & 4 & 20 & 4 & 400 & 400 & 90 \\
\hline 2 & $4 \mathrm{~K} \mathrm{He}$ return & 4 & 20 & 3.5 & 400 & 100 & 90 \\
\hline 3 & $4 \mathrm{~K}$ GHe return & 4 & 10 & 0.75 & 400 & 264 & 110 \\
\hline 4 & 20 K He supply & 14 & 20 & 3 & $200)$ & 200 & 90 \\
\hline 5 & $20 \mathrm{~K} \mathrm{He}$ retum & 28 & 20 & 2 & 200 & 200 & 110 \\
\hline 6 & $84 \mathrm{~K} \mathrm{LN}_{2}$ & 80 & 20 & 10 & TBD & $\mathrm{TBD}$ & 90 \\
\hline 7 & $84 \mathrm{~K} \mathrm{VN}_{2}$ & 84 & 10 & 1.2 & TBD & TBD & 110 \\
\hline 8 & $4 \mathrm{~K}$ He supply & 4.5 & 20 & 4 & 400 & 400 & 90 \\
\hline 9 & CCB GHe retum & 6.1 & 10 & 1.2 & 400 & 264 & 110 \\
\hline 10 & $4 \mathrm{~K} \mathrm{He}$ return & 4.3 & 20) & 3.5 & $400)$ & 100 & 9() \\
\hline 11 & Lead Flow & 300 & 20 & 1.5 & 54 & 36 & 110 \\
\hline
\end{tabular}




\section{SHAFT TRANSFER LINE (STL)}

The shaft transfer line.5 is the conduit for cryogen flow between SRS and the tunnel equipment. STL has seven lines: 4-K He supply, 4-K He return. GHe return, 2()-K supply, 2()-K return, and one line each for $84-\mathrm{K}$ liquid and vapor nitrogen, all enclosed in a common vacuum jacket.

There are ten shaft transfer lines for the collider and two for the HEB, all installed in the utility shafts at the midpoint of the sector. The total length of each STL depends on the depth of the individual utility shaft as well as the respective locations of the surface distribution box and the cold compressor box in the thinnel. STL will hang vertically on the wall of the utility shatt and have a vacuum pumpout port on each end. The shaft depths are given in Table 3, while Figure 3 shows design details of a transfer line.

The vacuum jacket can be made of $6(0)$-mm carbon steel pipe and will be designed to maintain a vacuum of $10{ }^{5} \mathrm{~Pa}$. An $8($ )-K thermal shield and multilayer insulation will be used to reduce heat leaks into the line. The estimated heat load for the STL is $0.1 \mathrm{~W} / \mathrm{m}$ for the $4-\mathrm{K}$ lines, ().3.3 W/m for the 20 - $\mathrm{K}$ lines. and $4.0 \mathrm{~W} / \mathrm{m}$ for the $84-\mathrm{K}$ lines. The STL will be built in standard straight modules $12 \mathrm{~m}$ long, with standard and special elbow pieces and special makeup pieces: it will be assembled on site. The estimated weight of a module is $150 \mathrm{~kg} / \mathrm{m}$.

\section{COLD COMPRESSOR BOX (CCB)}

Each sector requires a cold compressor module (see Figure 4), to be installed in the tunnel near the utility shaft. Twelve modules are needed-ten for the collider and two for the HEB. The cold compressor must follow the various operating modes-design, nominal, and standby - as determined by magnet system demand and refrigerator capacity and availability. Table 4 shows the design conditions for each mode with the minimum required isentropic efficiencies for the cold compressor.

The compressor shall be capable of safe start and shall continue to operate through a wide range of inlet and outlet temperatures, pressures, and flow rates. It is also necessary to be able to bring the compressor on line from room temperature with the rest of the system at the operating conditions. The system shall be designed with either a water or air cooling system, and high pressure helium gas will not be available for static gas bearing.

\section{HORIZONTAL TRANSFER LINE (HTL)}

A horizontal transfer line, which connects the cold compressor box and the tunnel distribution box, differs from the shaft transfer line only in its supports and installation. Whereas the STL will be supported vertically in the shaft, the HTL will be supported horizontally from the tunnel ceiling. The HTL for each sector will be approximately $23 \mathrm{~m}$ long and will have a vacuum pumpout port at each end. A total of 12 units will be required for the collider and HEB.

Table 3. Depth of shaft at each sector.

\begin{tabular}{ccccccccccccc}
\hline $\begin{array}{c}\text { Plant } \\
\text { Location }\end{array}$ & N15 & N25 & N35 & N45 & N55 & S15 & S25 & S35 & S45 & S55 & H20 & H60 \\
\hline Depth $(\mathrm{m})$ & 74 & 34 & 58 & 37 & 41 & 66 & 53 & 27 & 30 & 25 & 58 & 53 \\
\hline
\end{tabular}



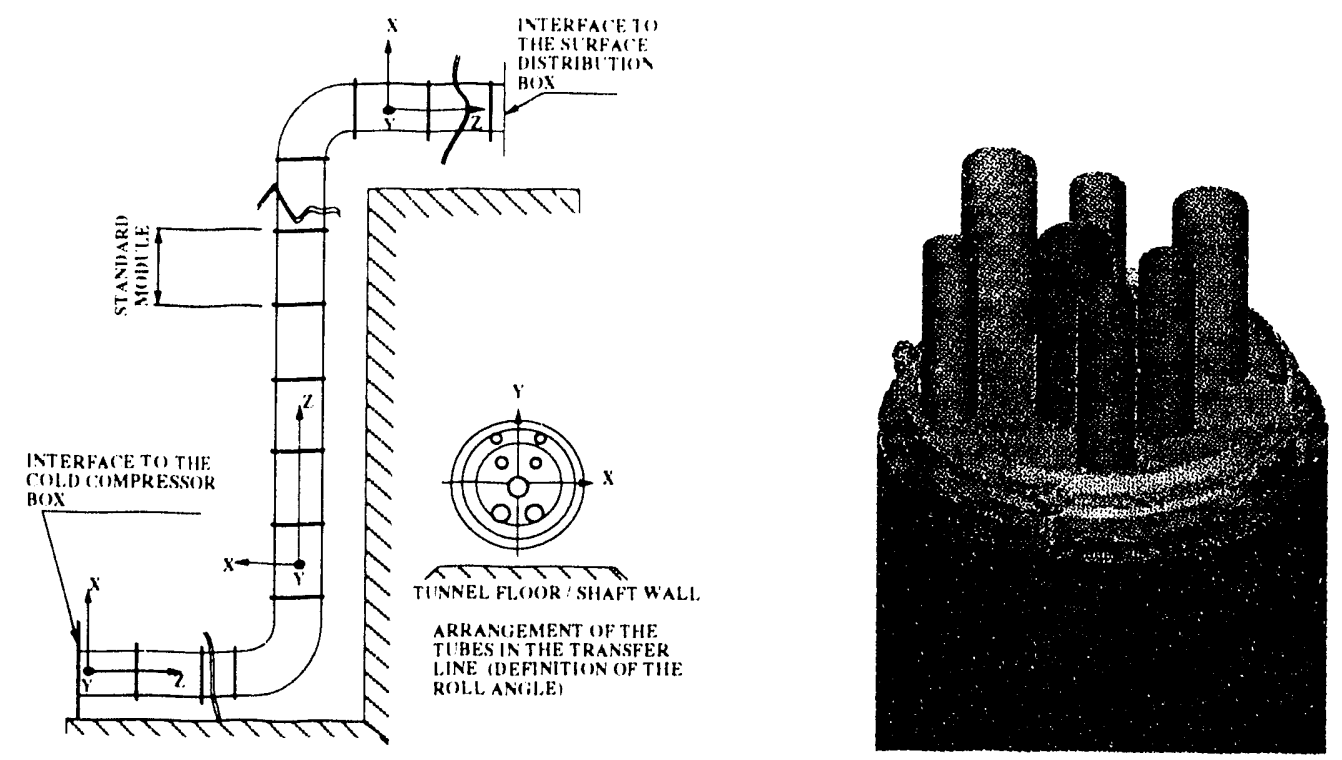

Figure 3. STL geometry and piping details.
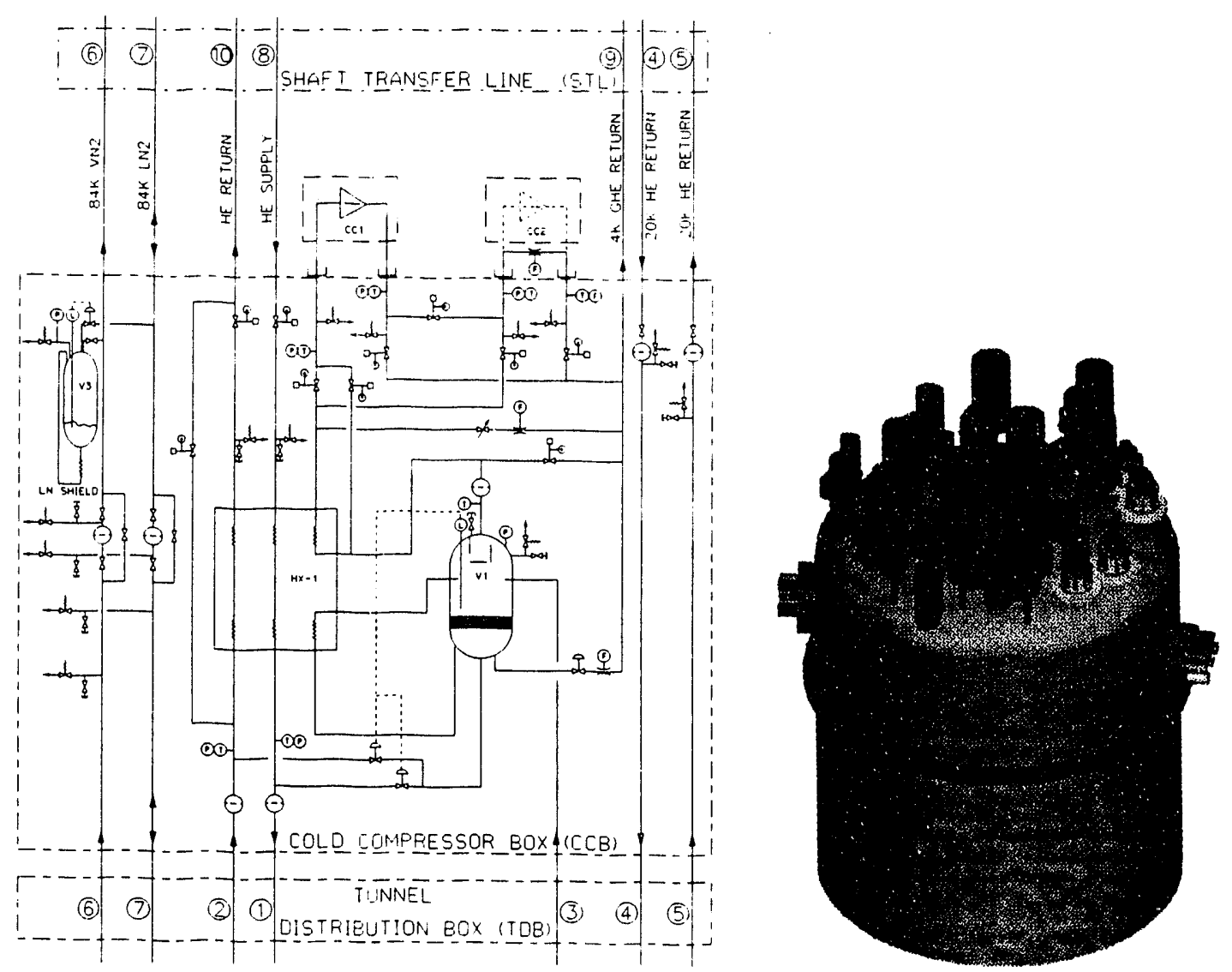

Figure 4. Cold compressor box (CCB). 
Table 4. cold compressor.

\begin{tabular}{|c|c|c|c|c|c|}
\hline \multirow{2}{*}{$\begin{array}{l}\text { Mode of } \\
\text { Operation }\end{array}$} & \multicolumn{2}{|c|}{ Inlet } & \multirow{2}{*}{$\frac{\text { ()utet }}{P \text { (bar) }}$} & \multirow{2}{*}{$\frac{M n \text { I:ff }}{\%}$} & \multirow{2}{*}{$\frac{I \operatorname{low}}{g / s}$} \\
\hline & P(har) & $\mathrm{T}(\mathrm{K})$ & & & \\
\hline Design & 0.75 & 43 & 1.45 & 6.5 & $33(1)$ \\
\hline Nominal & 0.75 & 4.3 & 1.4 & 60) & 264 \\
\hline Siandby & 0.75 & 4.3 & 1.35 & 55 & 138 \\
\hline
\end{tabular}

\section{TUNNEL DISTRIBUTION BOX (TDB)}

The tunnel distribution box (a nitrogen shielded coldbox) is designed for installation in a niche behind the feed spool. in the outer part of the ring. It shall be vacuum-jacketed (10 $\left.{ }^{5} \mathrm{~Pa}\right)$ and connected to the cold compressor box through the horizontal transfer line. The TDB itself has four short vacuum-jacketed transfer lines, each containing six pipes. feeding cryogens to) four magnet strings through the feed spool pieces. Figure 5 is a flow diagram for the TDB. Ten TDBs will be required for the collider. Since the HEB has only two strings, it requires only two short transfer lines on each of its two TDBs.
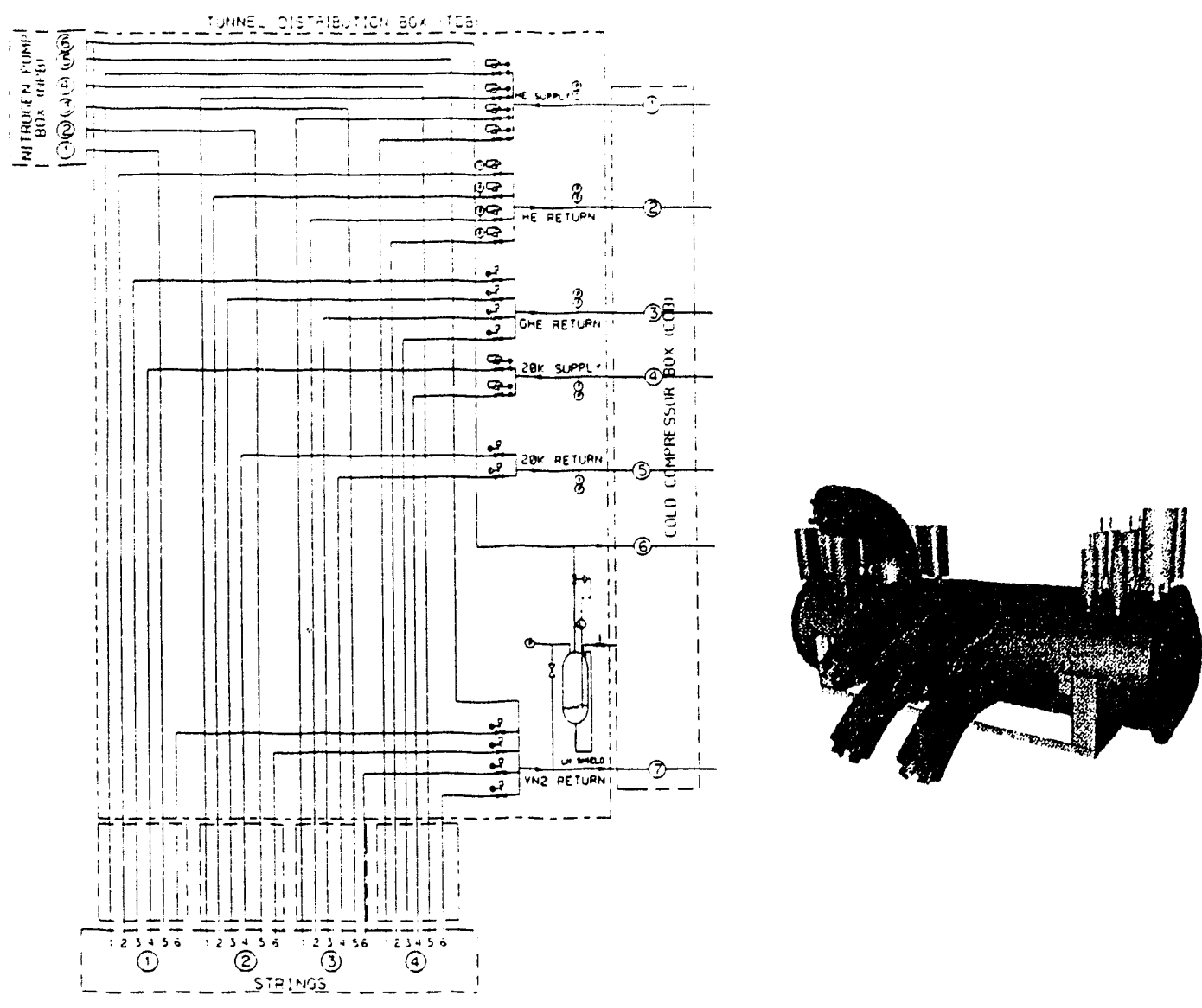

Figure 5. Tunnel distribution box (TDB) 


\section{NITROGEN PUMP BOX (NPB)}

Approximately 5()(x) g/s of liquid nitrogen is required for normal operation of the collider and the HEB. The liquid nitrogen will be imported to the SSC and delivered to one or more locations. From the delivery points it will be distributed around the rings for ring refrigeration and to the 12 helium refrigeration systems for helium precooling. The distribution of the nitrogen in the tunnel is done through the nitrogen pipes in the magnet strings. The flow is controlled by the nitrogen pump boxes, which are installed in the tunnel near the lunnel distribution boxes.

The NPB will contain a nitrogen subcooler, two (or more) pumps. and associated valves. One pump is used for circulation of the main flows and for distribution of the nitrogen in the tunnel. A second pump is required for pumping liquid nitrogen to the surface dewar, for the helium refrigerators. and for backup. The pumps will be configured for parallel operation and for interchangeable application.

The subcooler in the nitrogen pump box will be designed to support flow rates in each of two streams up to $20(0) \mathrm{g} / \mathrm{s}$, with heat loads up to $6(1)(0) \mathrm{W}$ per stream. The box will be an independent vacuum unit $\left(1()^{-5} \mathrm{~Pa}\right)$ and will have ports for pumping and monitoring instrumentation. Figure 6 is the flow diagram for the nitrogen pump box.

\section{NITROGEN DUMP TANKS (NDT)}

Two uninsulated nitrogen dump tanks will be installed in the niches near the feed spools, and two near the end spools of the sectors. These tanks will be used for emergency venting and may be used during cooldown and warmup. The capacity of the two tanks, $22,000 \mathrm{~L} \mathrm{(580)}$ gal), is equal to the total nitrogen inventory in two parallel strings (half a sector). The liquid nitrogen dumped into these tanks will vaporize and will be vented to the atmosphere through a pipe routed to the surface, as shown in Figure 6.

\section{NITROGEN SUBCOOLER BOX (NSB)}

To limit the temperature changes of the $84-\mathrm{K}$ shield, the liquid nitrogen must periodically be recooled. The expected heat load of the $84-\mathrm{K}$ system is around $3 \mathrm{~kW} / \mathrm{km}$ per string, and the maximum temperature of the liquid nitrogen should not exceed $89 \mathrm{~K}$. To cover the whole range of $\mathrm{LN}_{2}$ flows, including the smallest expected flow rates, the subcoolers will be located near the isolation spools (SPRI). The isolation spools are located every $1080 \mathrm{~m}$, and each has two cryostats connected to one another by six U-tubes, for the six streams in each magnet ring. Thus it seems reasonable to connect the $\mathrm{LN}_{2}$ subcoolers through these $\mathrm{U}$-tubes. Each two subcolers (top and bottom) will be incorporated in a single vessel but will have separate streams and controls. A total of 70 nitrogen subcooler boxes will be required for the collider and four for the HEB. Figure 7 is a flow diagram for the nitrogen subcoolers.

\section{AUXILIARY END BOX (AEB)}

A set of valves, connecting the six cryogenic lines of neighboring sectors, is required for the nitrogen flows across the sector boundaries during normal operation and for the helium flows when single-phase helium and/or 20-K helium must be transferred from one sector to the other ("assist" mode 3 ). The valve box may be designed as a separate box or may incorporate the nitrogen subcoolers. It will be connected to the center of the end spool, as shown in Figure 8. 

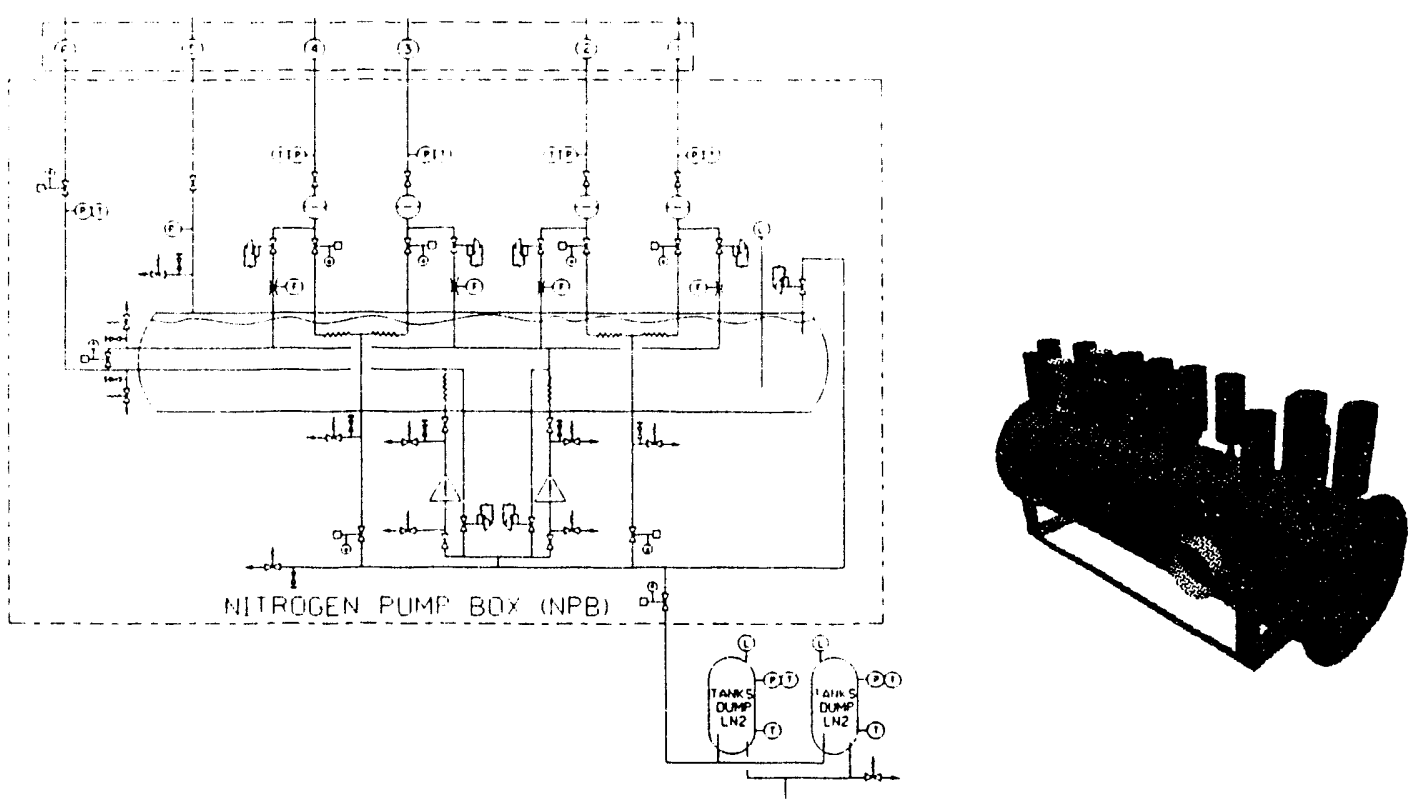

Figure 6. Nitrogen pump box (NPB).

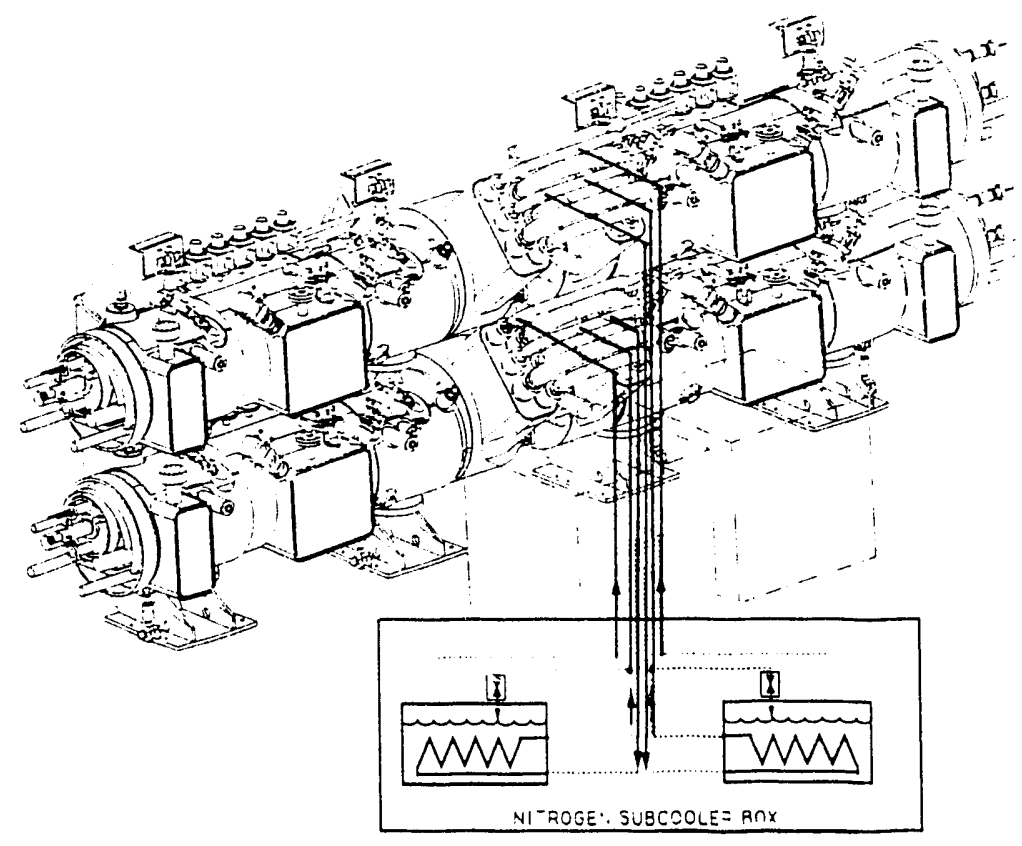

Figure 7. Nitrogen subcooler box (NSB). 


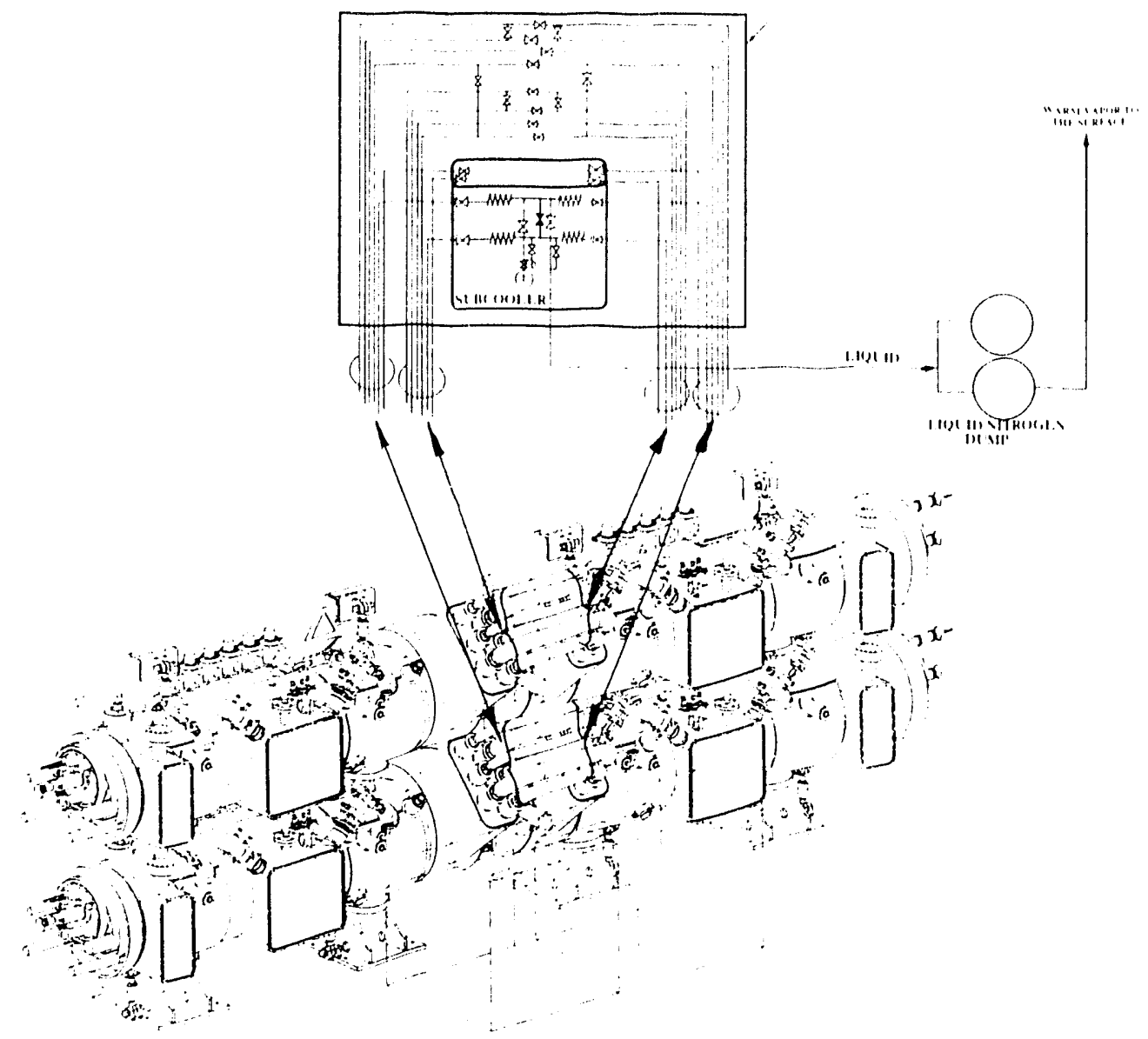

Figure 8. Auxiliary end box (AEB).

\section{CRYOGENIC BYPASS TRANSFER LINES (CBTL)}

In several parts of the collider rings and HEB, the beam tubes pass through warm equipment (magnets, scrapers, injection transfer lines, RF cavities, detectors, etc.). Cryogenic bypass transfer lines will be installed to bridge these regions, and high-current superconducting buses must be routed through the 4-K helium in these transfer lines. A total of $4100 \mathrm{~m}$ of bypass lines, consisting of 12 cryogenic lines, will be installed in the collider; $1300 \mathrm{~m}$ of bypass lines, consisting of 6 cryogenic lines, will be installed in the HEB. The CBTLs will be designed in standard 15-m modules, with end boxes (BPEB) where the connections to the magnet strings are made, and T-boxes (BPTB) where " $T$ " connections are needed to feed isolated cryostats. The end boxes will contain cryogenic measurement devices, relief and cooldown valves, and vacuum instrumentation. Every $90 \mathrm{~m}$ of the transfer line, a box with vacuum barrier, vacuum pumpout ports, and vacuum instrumentation is required. Provision must be made for bus expansion and contraction during cooldown and warmup. Figure 9 is the flow diagram for the BPEB and BPTB. 


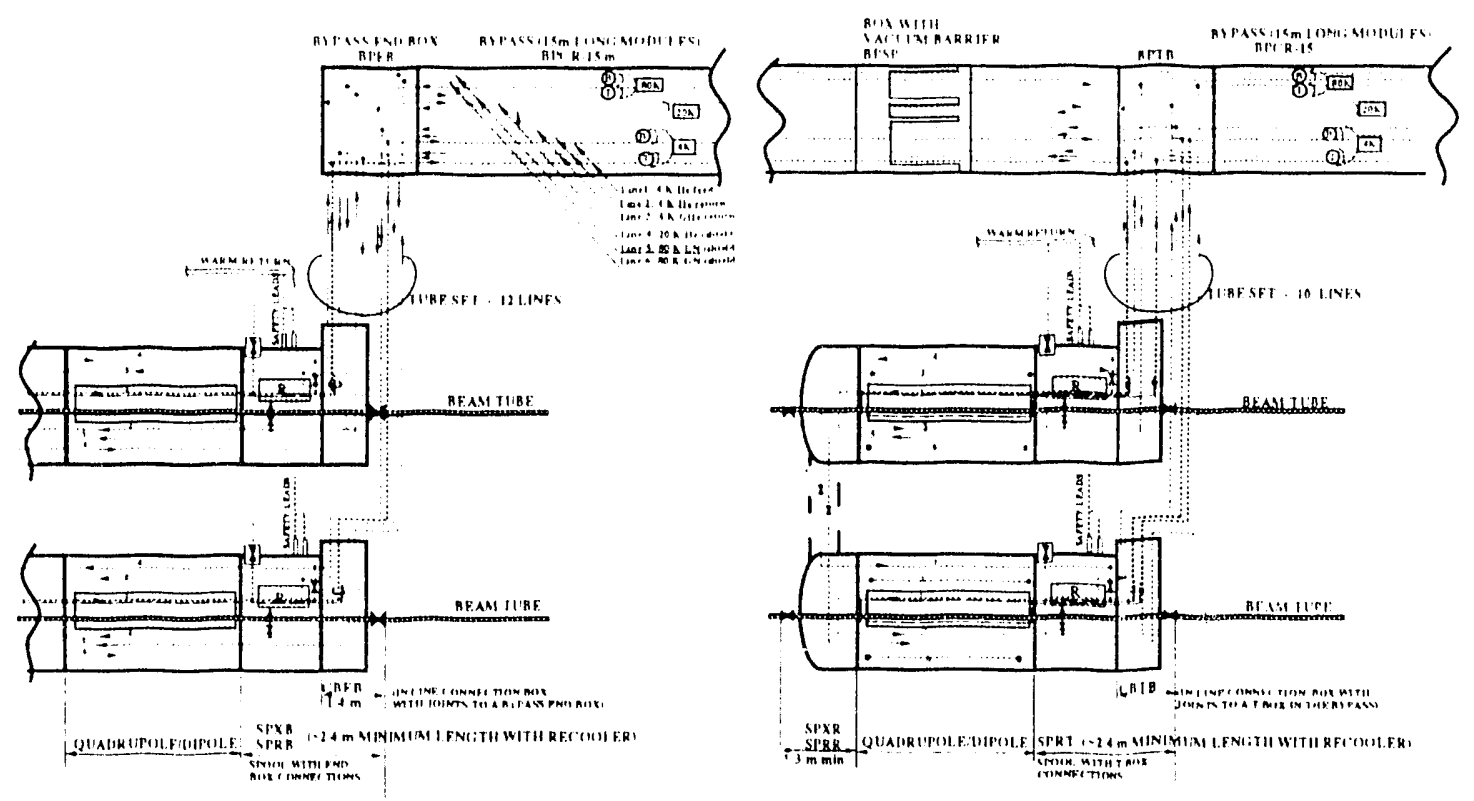

Figure 9. The BPEB and the BPTB.

\section{INSTRUMENTATION AND CONTROLS}

Instrumentation and process controls are part of the various cryogenic equipment such as spool pieces, bypass line end boxes, and other boxes described in the previous paragraphs. Signal conditioners, transmitters, and controllers will be installed in the underground niches.

\section{REFERENCES}

1. "Sector Refrigerator Surface System for the Collider Main Ring and High Energy Booster," Superconducting Supercollider Laboratory (SSCL) RFP SSC 93A-09339.

2. M.McAshan, V. Ganni, R. Than, and T. Nichaus, "Refrigeration plants for the SSC," in Supercollider 3: Proc. of the 3d Int'l Symposium on the Supercollider, Ma ch 1991, Atlanta, GA, Plenum Press, 1991.

3. R. Than, S. Abramovich, and V. Ganni, "The SSC cryogenic system design and operating modes," SSC Cryo Note 92-12, (October 1992.

4. M. McAshan, M. Thirumaleshwar, S. Abramovich, and V. Ganni, "Nitrogen system for the SSC," SSC:,-592, September 1992.

5. B. Zhang and K. Stifle, "Preliminary design of sector cryogenic shaft transfer line system," to be published in Supercollider 5: Proceedings of the 5th Int'l Symposium on the Supercollider, May 1993, San Francisco, CA, Plenum Press, New York (1993). 


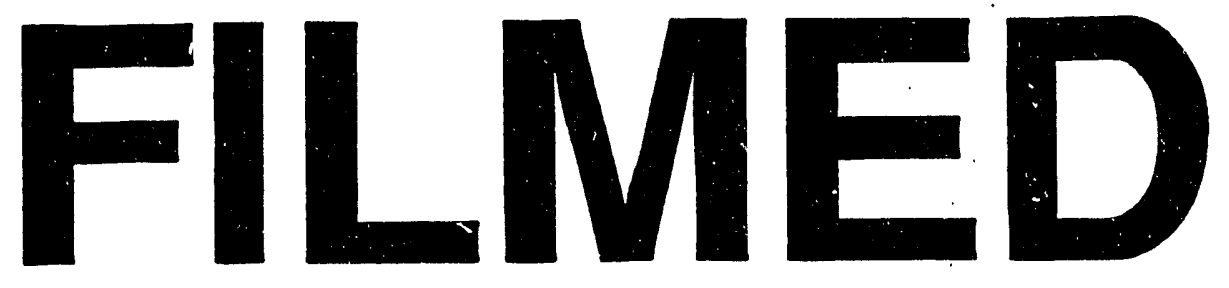

$11 / 10 / 93$
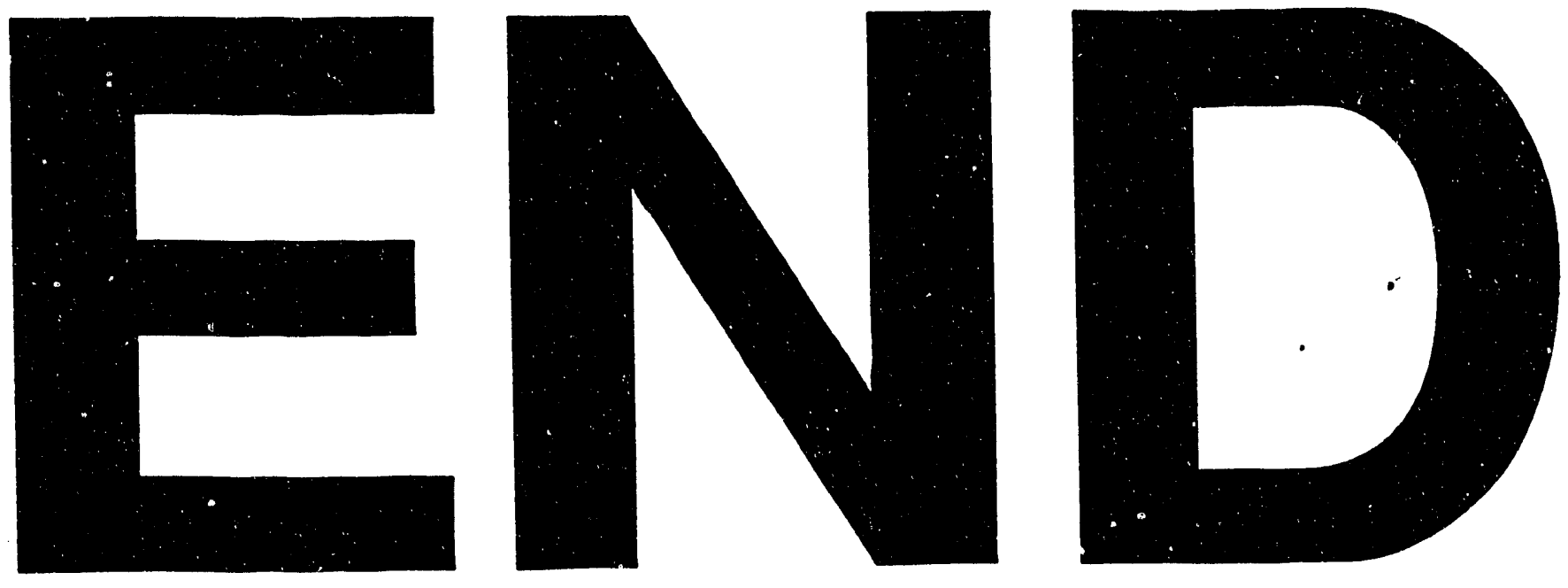
